\title{
Understanding and eliminating iron interference in colorimetric nitrate and nitrite analysis
}

\author{
Benjamin P. Colman
}

Received: 3 December 2008 / Accepted: 13 May 2009 / Published online: 3 June 2009

(C) The Author(s) 2009. This article is published with open access at Springerlink.com

\begin{abstract}
Across many environments, nitrate $\left(\mathrm{NO}_{3}^{-}\right)$is an important form of $\mathrm{N}$ available for microorganisms and photosynthetic organisms. Accurate $\mathrm{NO}_{3}^{-}$measurements are important for examining $\mathrm{N}$ cycling and retention in terrestrial and aquatic ecosystems, but a common method of $\mathrm{NO}_{3}^{-}$analysis can underestimate $\mathrm{NO}_{3}^{-}$concentrations when soluble iron is present (iron $>10 \mathrm{mg}$ $\mathrm{L}^{-1}$ ). The basic method is robust, using copperized cadmium to reduce $\mathrm{NO}_{3}^{-}$and then diazotizing the resulting $\mathrm{NO}_{2}^{-}$in a two-step process to form an easily measured colored product. We show that iron interference is unique to using an $\mathrm{NH}_{4} \mathrm{Cl}$ and ethylenediaminetetraacetic acid (EDTA) buffer. We hypothesize that interference is through iron-catalyzed reduction of the intermediate color product, a diazonium ion. We examine three historical buffers as alternatives to $\mathrm{NH}_{4} \mathrm{Cl} / \mathrm{EDTA}$ and recommend replacement of EDTA with diethylenetriaminepentaacetic acid, which chelates metals much like EDTA, but unlike EDTA, it does not cause interference in the presence of iron.
\end{abstract}

B. P. Colman $(\varangle)$

University of California, Santa Barbara,

CA, USA

e-mail: colmanb@gmail.com
Keywords Iron interference •

Colorimetric analysis $\cdot$ Nitrate $\cdot$ Nitrite

\section{Introduction}

Nitrate $\left(\mathrm{NO}_{3}^{-}\right)$is an important source of $\mathrm{N}$ for terrestrial and aquatic ecosystems, including groundwater, where it is the most common $\mathrm{N}$ form (Burkart and Stoner 2001). Given its prevalence in nature, it is important to be able to quantify $\mathrm{NO}_{3}^{-}$ accurately. For many years, one standard method for analyzing $\mathrm{NO}_{3}^{-}$has involved reducing it with copperized cadmium to nitrite $\left(\mathrm{NO}_{2}^{-}\right)$and then analyzing the $\mathrm{NO}_{2}^{-}$by reacting it first with sulfanilamide to form a diazonium ion and then with $N$-(1-napthyl)-ethylenediamine (NED) to form an azo dye (Fig. 1). However, recent work suggests that this method is vulnerable to interference from iron when buffered with an $\mathrm{NH}_{4} \mathrm{Cl}$ and ethylenediaminetetraacetic acid (EDTA) buffer (Vaughan et al. 1993; Colman et al. 2007), although the specific mechanism of inhibition has been unknown.

Iron interferes in $\mathrm{NO}_{3}^{-}$measurements as a function of its concentration (Vaughan et al. 1993). For example, Colman et al. (2007) showed that iron could cause up to $75 \%$ reduction in measured $\mathrm{NO}_{3}^{-}$when $\mathrm{Fe}$ concentrations were $100 \mathrm{mg} \mathrm{Fe}$ $\mathrm{L}^{-1}$ in $0.5 \mathrm{M} \mathrm{K}_{2} \mathrm{SO}_{4}$ (1:5 soil/extractant). This 


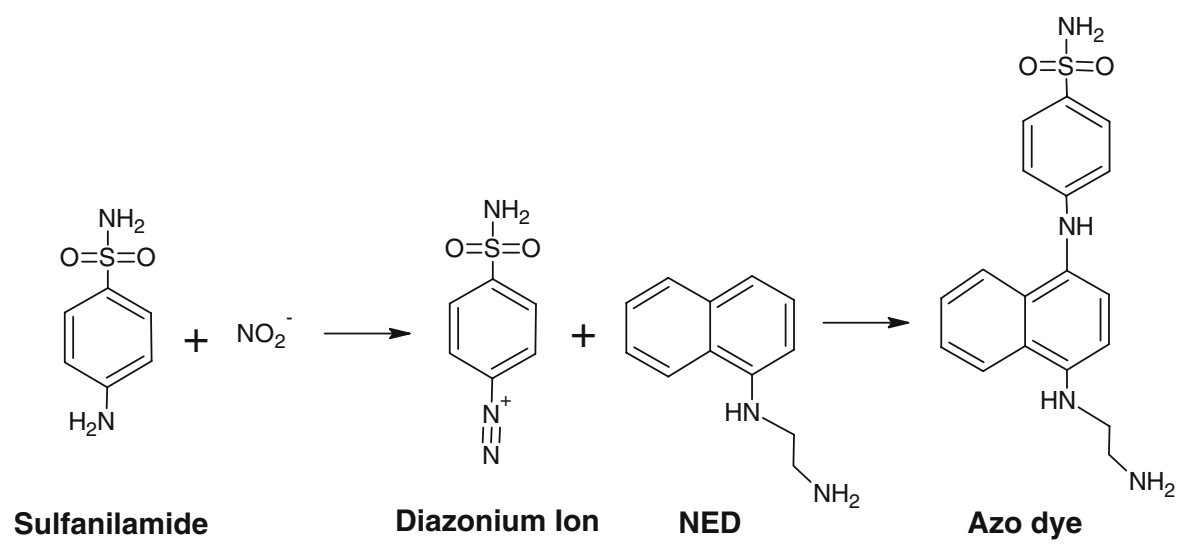

Fig. 1 Reaction scheme for colorimetric analysis of $\mathrm{NO}_{2}^{-}$

interference results from some combination of over- or underreduction of $\mathrm{NO}_{3}^{-}$to $\mathrm{NO}_{2}^{-}$, interference in the color formation steps, or the destruction of the final color product. Iron interference is only important if concentrations are high (>10 $\left.\mathrm{mg} \mathrm{L}^{-1}\right)$; however, iron concentrations in water and soil extracts can reach this level. In streamwater, Kimball et al. (2002) reported iron concentrations as high as $52.9 \mathrm{mg} \mathrm{L}^{-1}$ where a bog seep entered the stream and $127 \mathrm{mg} \mathrm{L}^{-1}$ downstream of mine tailings. In sediment pore waters of pit mine lakes, Herzsprung et al. (2005) found iron concentrations to be $>1,000 \mathrm{mg} \mathrm{L}^{-1}$. Numbers for iron in salt extracts of soil are scarce, as this is not the typical method for examining soluble iron in soils. While examining soluble iron was not the purpose of our previous work, we found that iron concentrations in $\mathrm{K}_{2} \mathrm{SO}_{4}$ extracts of autoclaved soils up to $216 \mathrm{mg} \mathrm{L}^{-1}$ (Colman et al. 2007). Brandtberg and Simonsson (2003) showed that $\mathrm{NH}_{4} \mathrm{Cl}$ extracts of aerobic forest soils had iron concentrations up to $121 \mathrm{mmol} \mathrm{kg}^{-1}$ (equivalent to $24 \mathrm{mg} \mathrm{L}^{-1}$ for a 1:5 soil/extractant ratio). Thus, even in aerobic soils, potentially soluble iron concentrations can be high enough to interfere in $\mathrm{NO}_{3}^{-}$measurement.

The current $\mathrm{NO}_{3}^{-}$analysis method grew from the nineteenth century work by Griess and Ilosvay, who developed a way to measure nitrite ( $\mathrm{NO}_{2}^{-}$; Griess 1879; Ilosvay 1889). It was refined by Shinn (1941), who replaced sulfamic acid with sulfanilamide to enhance sensitivity (giving the reaction in Fig. 1). In order to use this colorimetric method for nitrate, a suitable reducing agent was needed to convert $\mathrm{NO}_{3}^{-}$to $\mathrm{NO}_{2}^{-}-$ but no further-and give stable results regardless of sample matrix (freshwater, seawater, salt extracts, etc.). Copperized cadmium is perhaps the most commonly used reducing agent (Wood et al. 1967). When used with an appropriate buffer, it has high reduction efficiency, can be controlled so it does not reduce past $\mathrm{NO}_{2}^{-}$, and is stable regardless of sample matrix. The buffer must keep $\mathrm{pH}$ between 7.5 and 8.5 and keep $\mathrm{Cd}^{2+}$ ions (formed during reduction of dissolved $\mathrm{O}_{2}$ and $\mathrm{NO}_{3}^{-}$; Nydahl 1974) from precipitating in the column, and thereby causing decreased reduction capacity. Several different buffers have been used. Grasshoff (1964) suggested $\mathrm{NH}_{4} \mathrm{Cl}$ because it buffers within the optimal $\mathrm{pH}$ range and keeps $\mathrm{Cd}^{2+}$ ions in solution. Strickland and Parsons (1965) suggested using EDTA as both the buffer and the complexing agent, as it is a stronger ligand than $\mathrm{NH}_{4}^{+}$, and several other investigators followed suit (Brewer and Riley 1965; Wood et al. 1967). Several years later, however, Strickland and Parsons (1972) suggested reverting to the $\mathrm{NH}_{4} \mathrm{Cl}$ buffer recommended by Grasshoff (1964) as EDTA gave erratic results.

The first records we have found of a buffer using both $\mathrm{NH}_{4} \mathrm{Cl}$ and EDTA come from reports from the US Environmental Protection Agency (EPA; United States Environmental Protection Agency 1974; Gales and Booth 1975) and a 
contemporary paper from the Canadian Department of the Environment (Stainton 1974). The EPA (1974) document suggested using EDTA in conjunction with the $\mathrm{NH}_{4} \mathrm{Cl}$ buffer to counteract interference due to iron and copper, though the nature of the interference is not stated. In Stainton (1974), EDTA is in the buffer, but it gives no information as to why. It appears that the clearest explanation for the reintroduction of EDTA into the buffer chemistry comes from Gales and Booth (1975). In it, they use a powdered cadmium instead of granulated cadmium, and this choice of reactor material required using EDTA to eliminate column flow restriction due to precipitation of iron, even at low concentrations (1.6 $\left.\mathrm{mg} \mathrm{L}^{-1}\right)$. Flow restriction is a problem because at low flows, $\mathrm{NO}_{3}^{-}$is reduced past $\mathrm{NO}_{2}^{-}$to $\mathrm{NH}_{3} \mathrm{OH}^{+}$and $\mathrm{NH}_{4}^{+}$, decreasing analytical sensitivity and reliability. Separating the iron either chemically using a chelator or physically using dialysis (Herzsprung et al. 2005) minimizes the problems associated with precipitation. As for chemical interference of iron, Gales and Booth (1975) cites a paper in which Cd filings were used rather than powder, and there was no chemical interference using an $\mathrm{NH}_{4} \mathrm{Cl}$ buffer in soil solutions augmented with up to $10,000 \mathrm{mg} \mathrm{L}^{-1}$ of several metals, including iron (Henricksen and Selmer-Olsen 1970). Thus, it appears that EDTA was added to the $\mathrm{NH}_{4} \mathrm{Cl}$ buffer to prevent a physical interference that was unique to using powdered cadmium. However, using a buffer containing EDTA causes interference in analyzing $\mathrm{NO}_{3}^{-}$in samples that are high in iron (Colman et al. 2007). Also of interest, Gales and Booth (1975) showed that higher concentrations of EDTA resulted in lower recoveries of nitrate in the presence of iron indicating that EDTA may play a role in a chemical interference. One alternative buffer, in which EDTA is replaced with diethylenetriaminepentaacetic acid (DTPA) has been suggested and shown to be promising in eliminating iron interference (Vaughan et al. 1993), but has not been widely used, whereas $\mathrm{NH}_{4} \mathrm{Cl}, \mathrm{NH}_{4} \mathrm{Cl} / \mathrm{EDTA}$, and imidazole are all commonly used.

How do these buffers compare when faced with high-iron samples? What is the mechanism of iron interference? What buffer is best suited for rou- tine analysis of nitrate? To answer questions, we examined these four buffer solutions pulled from existing literature: $\mathrm{NH}_{4} \mathrm{Cl}$ (Grasshoff 1964, 1999), $\mathrm{NH}_{4} \mathrm{Cl}$ /EDTA (Stainton 1974; United States Environmental Protection Agency 1974; Gales and Booth 1975; QuickChem Method 10-107-04-1-A 1995), $\mathrm{NH}_{4} \mathrm{Cl} / \mathrm{DTPA}$ (Vaughan et al. 1993), and imidazole (Nydahl 1976; Patton et al. 2002). We examined the extent of interference by adding either $\mathrm{Fe}^{2+}$ or $\mathrm{Fe}^{3+}$ at each step of the analysis to evaluate the extent and mechanism of interference. We test other metals for possible effects on $\mathrm{NO}_{3}^{-}$measurement and then present evidence for the mechanism by which iron interferes with $\mathrm{NO}_{3}^{-}$ analysis. Given the extent and nature of the interference and the presence of high iron in some soil and stream solutions, we propose that the buffer be changed from $\mathrm{NH}_{4} \mathrm{Cl} /$ EDTA to $\mathrm{NH}_{4} \mathrm{Cl} / \mathrm{DTPA}$.

\section{Materials and methods}

\section{Buffers and color reagent}

Four separate buffers were evaluated: $\mathrm{NH}_{4} \mathrm{Cl}$, $\mathrm{NH}_{4} \mathrm{Cl}$ with EDTA, $\mathrm{NH}_{4} \mathrm{Cl}$ with DTPA (diethylenetriaminepentaacetic acid), and imidazole. The $\mathrm{NH}_{4} \mathrm{Cl}$ buffer was made by adding $85 \mathrm{~g}$ of $\mathrm{NH}_{4} \mathrm{Cl}$ to $800 \mathrm{~mL}$ of deionized (DI) water. The $\mathrm{pH}$ is adjusted to 8.5 with $15 \mathrm{~N} \mathrm{NaOH}$, then the solution was mixed to $1 \mathrm{~L}$. The buffers with EDTA and DTPA are the same $\mathrm{NH}_{4} \mathrm{Cl}$ buffer, but with $1 \mathrm{~g}$ of either EDTA or DTPA added. The imidazole buffer is made by adding $6.8 \mathrm{~g}$ of imidazole to $900 \mathrm{~mL}$ DI water, adjusting the $\mathrm{pH}$ to 7.5 using concentrated $\mathrm{HCl}$, and then adding $1 \mathrm{~mL}$ of $2 \% \mathrm{Cu} w / v$ using a $\mathrm{CuSO}_{4} \cdot 5 \mathrm{H}_{2} \mathrm{O}$ solution, and diluting to $1 \mathrm{~L}$.

Two different versions of color reagent were used: one mixed reagent for measuring $\mathrm{NO}_{3}^{-}$and $\mathrm{NO}_{2}^{-}$with the Lachat Flow injection analyzer and one separated color reagent for use in manual $\mathrm{NO}_{2}^{-}$determinations. The color reagent used with the flow injection analyzer is made with $100 \mathrm{~mL}$ of $85 \%$ phosphoric acid $\left(\mathrm{H}_{3} \mathrm{PO}_{4}\right), 40.0 \mathrm{~g}$ sulfanilamide, and $1.0 \mathrm{~g}$ NED diluted to $1 \mathrm{~L}$ with DI water. For manual $\mathrm{NO}_{2}^{-}$determination, the color reagent was separated into two solutions: the first an acidic sulfanilamide solution $(100 \mathrm{~mL} 85 \%$ 
$\mathrm{H}_{3} \mathrm{PO}_{4}$ and $40 \mathrm{~g}$ sulfanilamide, diluted to $500 \mathrm{~mL}$ ) and the second a straight NED solution (1 g NED, mixed to $500 \mathrm{~mL}$ ). Both solutions were twice the concentration of their respective components in the mixed color reagent so that when equal portions of the two were added, they were equivalent to the mixed reagent. This hand chemistry is similar to that of Bendschneider and Robinson (1952).

\section{Colorimetric analyses}

Analyses of $\mathrm{NO}_{3}^{-}$and $\mathrm{NO}_{2}^{-}$were performed using a Lachat 2300 flow injection analyzer (Lachat Instruments, Milwaukee, USA), and manual $\mathrm{NO}_{2}^{-}$analyses were performed on a DU-800 Spectrophotometer (Beckman Coulter, Fullerton, USA). Details on the operation and sample manifolds for the Lachat can be found in QuickChem Method 10-107-04-1-A (1995). To manually measure $\mathrm{NO}_{2}^{-}$, we used the Lachat mixing ratio, which is $\sim 4.4: 1.3: 1$ buffer to sample to color reagent. We added $\mathrm{NO}_{2}^{-}$, buffer, and then sulfanilamide, let it react for $1 \mathrm{~min}$, added NED, and then let it react for one more minute before measuring the developed color. Iron was added either before sulfanilamide, after sulfanilamide, or after NED. Samples were analyzed in a $1 \mathrm{~cm}$ quartz cuvette at $543 \mathrm{~nm}$.

\section{Experiments}

\section{Test of iron interference with different buffers}

Iron interference was determined for $\mathrm{NH}_{4} \mathrm{Cl}$, $\mathrm{NH}_{4} \mathrm{Cl} / \mathrm{EDTA}, \mathrm{NH}_{4} \mathrm{Cl} / \mathrm{DTPA}$, and imidazole buffers using the Lachat flow injection analyzer (Fig. 1). The concentration of a $3 \mathrm{mg} \mathrm{L}^{-1} \mathrm{NO}_{3}^{-}-$ $\mathrm{N}$ solution was measured with iron concentrations of 200, 100, 50, and $0 \mathrm{mg} \mathrm{Fe}^{2+} \mathrm{L}^{-1}$ (from 1,000 mg $\mathrm{Fe}^{2+} \mathrm{L}^{-1}$ as $\mathrm{Fe}(\mathrm{II}) \mathrm{Cl}_{2}$ in $2 \% \mathrm{HCl}$ from High $\mathrm{Pu}-$ rity Standards no. 100026-2). Each standard and sample was run in triplicate, with average values and standard deviations presented here.

\section{Test of other metal interferences}

While we found only $\mathrm{Cu}$ and Fe indicated in the literature as potentially causing interference with nitrate analysis, we decided to test these and several other possible interfering metals, namely aluminum, manganese, and zinc (Fig. 3). These metals were chosen because they can all be found in soil solutions, are transition elements (with the exception of aluminum), and all are possibly redox active given a strong reductant, a characteristic we hypothesize may be important to analytical interference. We used $\mathrm{AlCl}_{3}, \mathrm{CuSO}_{4}, \mathrm{FeCl}_{2}, \mathrm{MnCl}_{2}$, and $\mathrm{ZnSO}_{4} 1,000 \mathrm{mg} \mathrm{L}^{-1}$ stock solutions. Samples were made by dilution to $100 \mathrm{mg} \mathrm{L}^{-1}$, with metals being added singly, in pairwise combinations, and a combination of all metal ions. While these ions only represent one oxidation state for each metal, these are forms likely to persist in soils and soil solutions.

\section{Mode of interference}

To determine which form(s) of iron interferes with $\mathrm{NO}_{3}^{-}$measurement and gain insight into mechanism, we first tested to see if interference is in the reduction step (Fig. 4). We compared analyses of $\mathrm{NO}_{2}^{-}$on the Lachat autoanalyzer, both with the $\mathrm{Cd}$ reduction column online and offline, and using either $\mathrm{Fe}^{2+}$ or $\mathrm{Fe}^{3+}$ as iron sources $\left(\mathrm{Fe}^{3+}\right.$ as EDTA ferric sodium salt trihydrate, Acros Organics). If interference is due to underreduction of $\mathrm{NO}_{3}^{-}$to $\mathrm{NO}_{2}^{-}$, then $\mathrm{NO}_{2}^{-}$should show no signs of interference. If interference is due to overreduction of $\mathrm{NO}_{3}^{-}$by the Cd column in the presence of iron, we would expect $\mathrm{NO}_{2}^{-}$to have problems similar to those of $\mathrm{NO}_{3}^{-}$with the column online and no interference when the column is offline.

To examine for interference in color formation, we used manual chemistry and made sequential additions of the various reactants (Fig. 5). Iron was added before adding sulfanilamide and NED or after adding sulfanilamide but before adding NED to test for interference in diazonium ion or azo-dye formation steps, respectively. To test whether iron could disrupt the final azo dye after it formed, we added Fe after adding both sulfanilamide and NED. We also did a variation where iron was added, then sulfanilamide and NED were added simultaneously to see if this gave different results. Iron and $\mathrm{NO}_{2}^{-}$were added to give final concentrations of $100 \mathrm{mg} \mathrm{L}^{-1} \mathrm{Fe}^{2+}$ and $0.5 \mathrm{mg} \mathrm{L}^{-1}$ $\mathrm{NO}_{2}^{-}-\mathrm{N}$, respectively. 


\section{Results and discussion}

Test of buffers

The $\mathrm{NH}_{4} \mathrm{Cl}, \mathrm{NH}_{4} \mathrm{Cl} / \mathrm{DTPA}$, and imidazole buffers all gave accurate $\mathrm{NO}_{3}^{-}$measurement in the presence of iron for all iron concentrations (Fig. 2). Only the $\mathrm{NH}_{4} \mathrm{Cl} / \mathrm{EDTA}$ buffer showed iron interference in $\mathrm{NO}_{3}^{-}$measurements. Given that $\mathrm{NH}_{4} \mathrm{Cl}$ alone had no interference, the EDTA clearly enables iron to interfere. Both EDTA and DTPA, interestingly, appeared to enhance column stability. When analyzing samples containing iron and using either $\mathrm{NH}_{4} \mathrm{Cl}$ or imidazole buffer with a cadmium column that was near the end of its life, the column reduction efficiency dropped steadily. When the buffer was switched to $\mathrm{NH}_{4} \mathrm{Cl} /$ EDTA or $\mathrm{NH}_{4} \mathrm{Cl} / \mathrm{DTPA}$, reduction efficiency returned to its previous level very rapidly and remained fairly steady over the course of analyses with these buffers. We suggest that the declining column reduction efficiency is likely the result of precipitation of Fe oxyhydroxides on the column surface (Herzsprung et al. 2005). When $\mathrm{Fe}^{2+}$ was added to aliquots of either the $\mathrm{NH}_{4} \mathrm{Cl}$ or imidazole buffers, a visible rust-colored precipitate forms (personal observation), but little to no visible precipitate forms when $\mathrm{Fe}^{2+}$ is added to $\mathrm{NH}_{4} \mathrm{Cl} /$ EDTA or $\mathrm{NH}_{4} \mathrm{Cl} / \mathrm{DTPA}$, presumably because they chelate iron and keep it in solution. It should be noted

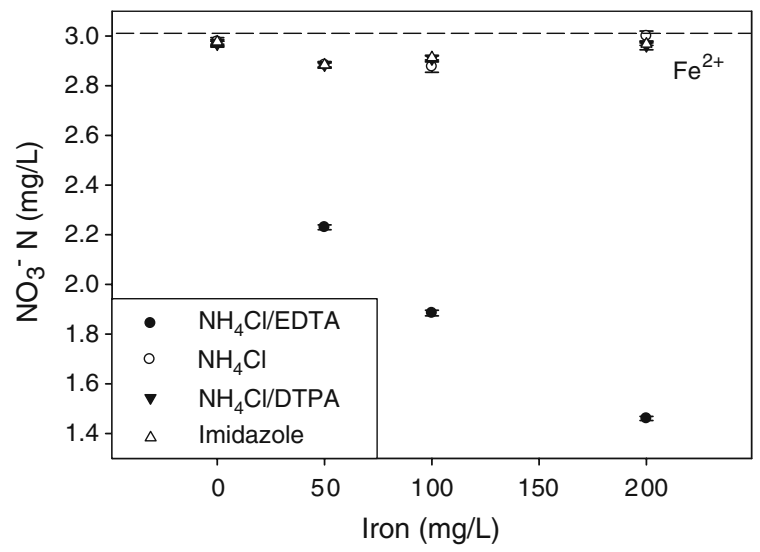

Fig. 2 Nitrate concentration of a $3 \mathrm{mg} \mathrm{L}^{-1} \mathrm{NO}_{3}^{-}-\mathrm{N}$ solution measured for different concentrations of iron with all four buffers. Each point represents the average of three analytical replicates, and error bars are standard deviation that this underreduction due to precipitation on copperized cadmium surfaces is distinct from the interference in Gales and Booth (1975), which was caused by a decrease in flow rate resulting in overreduction. This may also give some insight into how $\mathrm{NH}_{4} \mathrm{Cl}$ and imidazole avoid interference problems; since iron precipitates out, it cannot cause interference in later reaction steps.

\section{Metal interferences}

We chose five metal ions likely to be in soil solution and which might be potential interferrants with $\mathrm{NO}_{3}^{-}$analysis. In the tests of different metals, the only metal that interfered was iron (Fig. 3). The degree of interference was identical for iron singly, pairwise with other metals, and with all other metals simultaneously present. This indicates that iron does not act synergistically with any other metals we tested.

\section{Mode of interference}

To test for iron interference in the reduction step with the $\mathrm{NH}_{4} \mathrm{Cl} / \mathrm{EDTA}$ buffer, we added either $\mathrm{Fe}^{2+}$ or $\mathrm{Fe}^{3+}$ to $\mathrm{NO}_{2}^{-}$and measured concentration either with the reduction column online and offline. With the column online, we saw the same pattern of iron interference for $\mathrm{NO}_{2}^{-}$as we did for $\mathrm{NO}_{3}^{-}$. Since nitrite does not need reduction, but we still saw interference, this indicates that the interference is not due to underreduction of $\mathrm{NO}_{3}^{-}$(Fig. 4) by the cadmium column, consistent with the findings of Davidson et al. (2008). We saw a slightly stronger interference from $\mathrm{Fe}^{3+}$ than we do from $\mathrm{Fe}^{2+}$. The $\mathrm{Fe}^{3+}$ used was iron edetate, which added more EDTA, and as Gales and Booth (1975) showed, higher EDTA concentrations can lead to lower measureable $\mathrm{NO}_{3}^{-}$in the presence of iron.

We still see interference with $\mathrm{Fe}^{2+}$ with the cadmium reduction column offline, indicating that the interference is not due to $\mathrm{NO}_{3}^{-}$overreduction by the cadmium column. Rather, it must be in the color formation steps. Interestingly, there is no interference with $\mathrm{Fe}^{3+}$ when the column is offline, but there is when the column is online. Thus, it appears that $\mathrm{Fe}^{3+}$ gets reduced to $\mathrm{Fe}^{2+}$ by the reduction column and that $\mathrm{Fe}^{2+}$ is the active form in the 


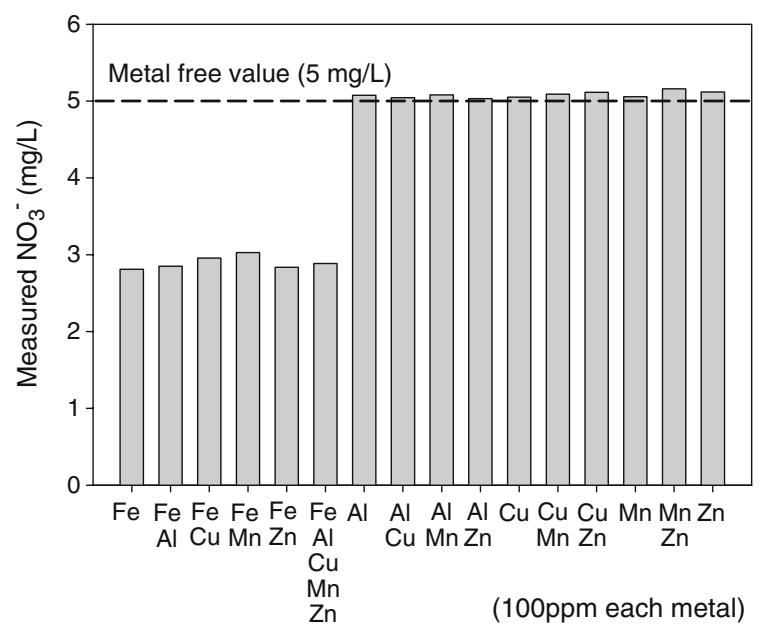

Fig. 3 Nitrate concentration measured in the presence of metal ions singly, in pairs, or all together

interference. While we did not measure $\mathrm{Fe}^{2+}$ and $\mathrm{Fe}^{3+}$ leaving the cadmium reduction column, this is consistent with the reduction potentials $\left(E^{\circ}\right)$ of the two metals. The $E^{\mathrm{o}}$ for $\mathrm{Fe}^{3+}$ is 0.77 , and $E^{o}$ for $\mathrm{Cd}$ is -0.4 , making the difference $\Delta E^{0}=E_{\mathrm{Fe}^{3+}}^{0}-$ $E_{\mathrm{Cd}}^{0}=1.17 \mathrm{~V}$. Since this number is positive, we would expect a spontaneous reaction, which is confirmed by experiments which showed that $\mathrm{Fe}^{3+}$ is reduced by metals in sewage sludge including cadmium (Ito et al. 2000).

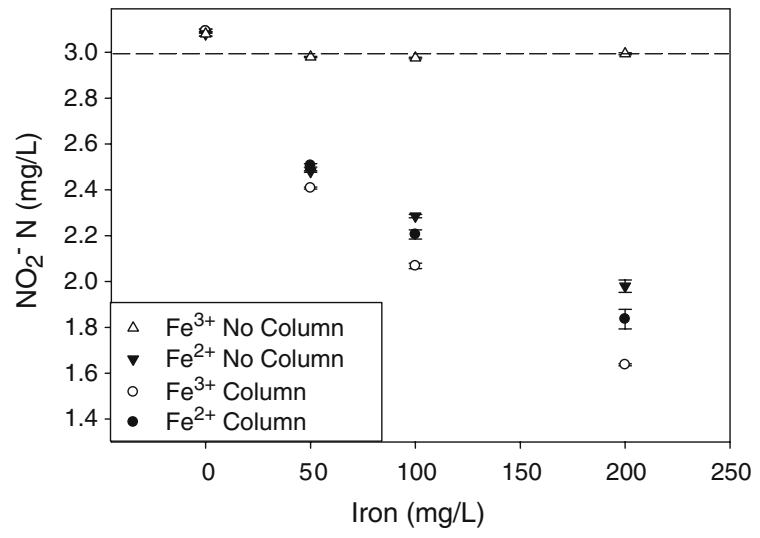

Fig. 4 Nitrite concentration of $3 \mathrm{mg} \mathrm{L}^{-1} \mathrm{NO}_{2}^{-}-\mathrm{N}$ solutions measured for different concentrations of $\mathrm{Fe}^{3+}$ or $\mathrm{Fe}^{2+}$ with the cadmium column online or offline. Each point represents the average of three analytical replicates, and error bars are standard deviation
From these experiments, we know that the interference is in color development, and the oxidation state of iron matters, though non-interfering $\mathrm{Fe}^{3+}$ seems to be reduced to $\mathrm{Fe}^{2+}$ in the cadmium column. To determine where in the color development process $\mathrm{Fe}^{2+}$ interferes, we used hand chemistry to measure $\mathrm{NO}_{2}^{-}$concentration and added iron before adding sulfanilamide, after sulfanilamide, and after NED (refer to reaction scheme in Fig. 1). There was no color development when iron was added before NED addition, regardless of whether it was added before sulfanilamide or after (Fig. 5). This indicates that interference is not due to blocking the reaction of $\mathrm{NO}_{2}^{-}$with sulfanilamide. After adding NED, subsequent iron addition had no effect on measured nitrite. This shows that iron does not destroy the final azo dye, but rather, it prevents its formation by interfering with the reaction of NED with the diazo intermediate. When sulfanilamide and NED are added simultaneously to a sample that already contains iron and $\mathrm{NO}_{2}^{-}$, there is some color development (Fig. 5). This matches the results of flow injection analyzer analyses in which a mixed color reagent is used and suggests that the mechanism is a competitive reaction between iron and NED for the diazo intermediate.

These results suggest a mechanism for interference involving $\mathrm{Fe}^{2+}$, with EDTA potentially playing a role in the interference. Reducing agents

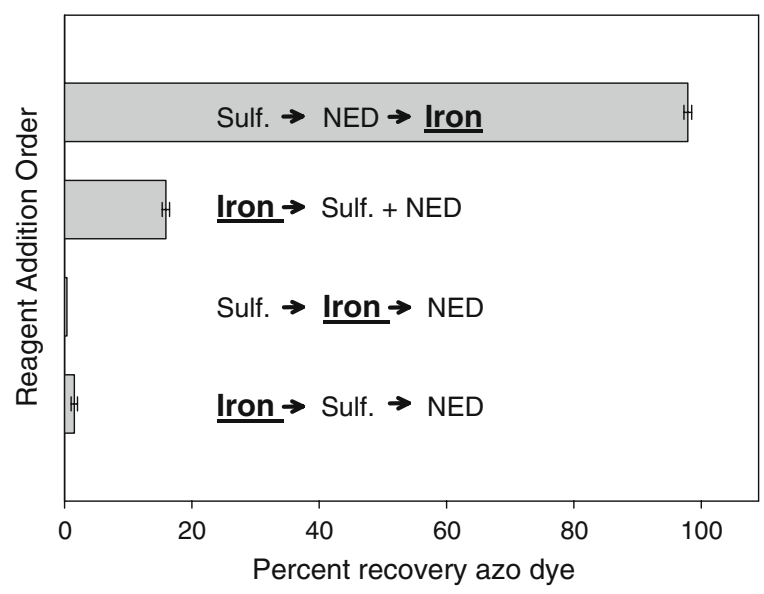

Fig. 5 Percent recovery of azo dye in sequential addition experiments, error bars are standard deviation of three replicate samples 


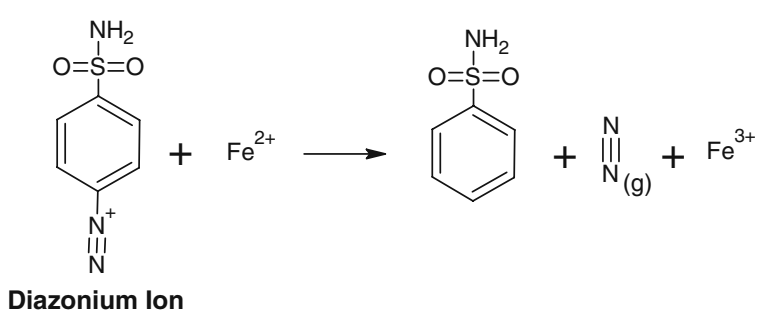

Fig. 6 Proposed mechanism of interference by iron through reduction of azo dye by ferrous iron

can lead to the loss of azide $\left(\mathrm{R}-\mathrm{N}^{+} \equiv \mathrm{N}\right)$ groups on benzene diazonium ions such as that formed by the complexation of $\mathrm{NO}_{2}^{-}$with sulfanilamide (Vollhardt and Schore 1994). In fact, Gilbert et al. (1992) showed that Fe(II)EDTA at pH 9 causes the loss of azide from several very similar benzene diazonium ions. Thus, we hypothesize that $\mathrm{Fe}$ (II)EDTA reduces the diazonium ion (see Fig. 6), preventing formation of the desired azo dye. If $\mathrm{Fe}^{2+}$ is added to the diazonium ion in the absence of NED, all diazonium is reduced. If sulfanilamide and NED are added simultaneously, then the NED and $\mathrm{Fe}^{2+}$ compete for diazonium with some forming azo-dye product and some being reduced.

Why does this problem not occur with the other buffers? Some insight comes from our observation that column efficiency declines when using the $\mathrm{NH}_{4} \mathrm{Cl}$ or the imidazole buffer. Assuming that the decrease in column efficiency is due to iron precipitation, the iron is then unavailable to reduce the diazonium ion and therefore cannot interfere. This is consistent with the findings in Herzsprung et al. (2005), which suggests that iron precipitates could cause column fouling and even light scattering in the detector. With both the $\mathrm{NH}_{4} \mathrm{Cl} / \mathrm{DTPA}$ and $\mathrm{NH}_{4} \mathrm{Cl} /$ EDTA buffers, the iron is kept in solution, but with DPTA there is no interference up to $200 \mathrm{mg} \mathrm{L}^{-1}$ Fe. We suggest that since DTPA can act as an octadentate ligand (three tertiary amines with lone electron pairs and five carboxylic acid groups, see Fig. 7), it completely sequesters the iron and prevents its reaction with the diazonium ion. Since EDTA is only a hexadentate ligand (two tertiary amines with lone electron pairs and four carboxylic acid groups), iron has two orbitals free to interact with the diazonium ion. Not only this, but EDTA lowers the reduction potential of iron from 0.77 to 0.14 and thereby makes it a better reductant and increases the favorability of reduction of diazonium (Gilbert et al. 1992). Thus, EDTA appears to selectively create the interference with $\mathrm{NO}_{3}^{-}$and $\mathrm{NO}_{2}^{-}$analyses.

While $\mathrm{NH}_{4} \mathrm{Cl} /$ EDTA has been a standard buffer for over 35 years, the claim propagated over time that EDTA is added to remove iron interference is only half true; when using a cadmium column with powdered cadmium, EDTA eliminates the interference which is caused by metal precipitates, which cause blockage and slow flow rates, which leads to overreduction. When using a cadmium column with granulated cadmium, blockage is much less of an issue, but EDTA does help lessen the correctable drift due to precipitation of metals and decreasing reduction
Fig. 7 Structure of diethylenetriaminepentaacetic acid $(D T P A)$ and ethylenediaminetetraacetic acid (EDTA), with coordinating atoms in dashed circles

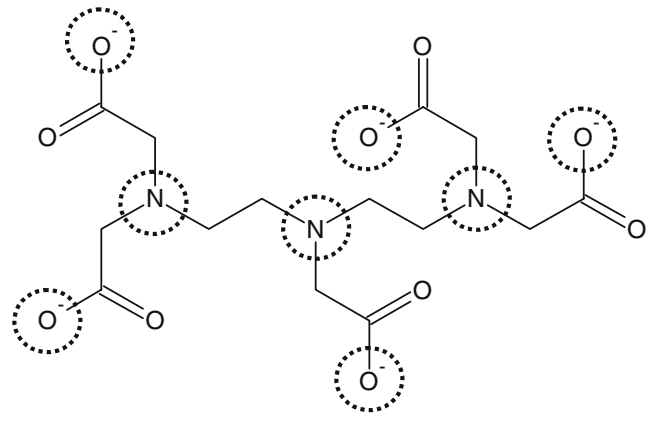

diethyltriaminopentaacetic acid (DTPA)

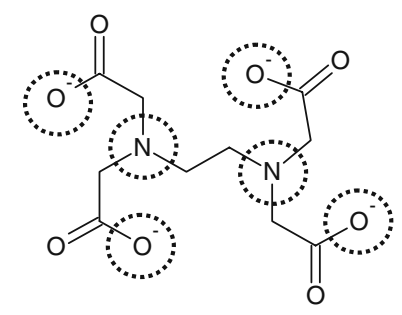

ethylenediaminetetracetic acid (EDTA) 
column efficiency. However, at high-iron concentrations, it introduces a much more serious, unanticipated, and uncorrectable source of analytical error. One can reasonably assume that most natural waters and soil solutions will be low in iron; however, when dealing with anaerobic systems, metal contaminated sites, and soils or sediments that have been disturbed through sterilization techniques known to increase iron concentration, using $\mathrm{NH}_{4} \mathrm{Cl} /$ EDTA buffer will cause underestimation of $\mathrm{NO}_{3}^{-}$and $\mathrm{NO}_{2}^{-}$concentrations. Rather than periodically testing to see if iron might be interfering in a given set of analyses, and since the levels of iron that are necessary to cause interference are not unreasonably high and can occur in natural waters and soil extracts, we suggest a change in buffer used for these analyses. Both straight $\mathrm{NH}_{4} \mathrm{Cl}$ and imidazole avoid iron interference in the color development and thus provide accurate $\mathrm{NO}_{3}^{-}$analyses, but they allow for more rapid degradation of the reduction capacity of the $\mathrm{Cd}$ reduction column. Adding a chelator is thus necessary for accurate and precise measurement of nitrate. Of the four buffers investigated, only $\mathrm{NH}_{4} \mathrm{Cl} / \mathrm{DTPA}$ eliminated both degradation of the $\mathrm{Cd}$ column and iron interference in color development and accurate $\mathrm{NO}_{3}^{-}$analyses. It is thus the "best" buffer for $\mathrm{NO}_{3}^{-}$and $\mathrm{NO}_{2}^{-}$analyses out of these four historical buffers and should become a candidate for the standard buffer for the standard analytical method.

Open Access This article is distributed under the terms of the Creative Commons Attribution Noncommercial License which permits any noncommercial use, distribution, and reproduction in any medium, provided the original author(s) and source are credited.

\section{References}

Bendschneider, K., \& Robinson, R. J. (1952). A new spectrophotometric method for the determination of nitrite in sea water. Journal of Marine Research, 11(1), 87-96.

Brandtberg, P. O., \& Simonsson, M. (2003). Aluminum and iron chemistry in the $\mathrm{O}$ horizon changed by a shift in tree species composition. Biogeochemistry, 63(2), 207228. doi:10.1023/A:1023303023695.
Brewer, P. G., \& Riley, J. P. (1965). The automatic determination of nitrate in sea water. Deep Sea Research and Oceanographic Abstracts, 12(6), 765. doi:10.1016/0011-7471(65)90797-7.

Burkart, M. R., \& Stoner, J. D. (2001). Nitrogen in groundwater associated with agricultural systems. In R. F. Follett \& J. L. Hatfield (Eds.), Nitrogen in the environment: Sources, problems and management. Amsterdam: Elsevier Science.

Colman, B. P., Fierer, N., \& Schimel, J. P. (2007). Abitoic nitrate incorporation in soil: Is it real? Biogeochemistry, 84, 161-169. doi:10.1007/s10533-007-9111-5.

Davidson, E. A., Dail, D. B., \& Chorover, J. (2008). Iron interference in the quantification of nitrate in soil extracts and its effect on hypothesized abiotic immobilization of nitrate. Biogeochemistry, 90(1), 65-73. doi:10.1007/s10533-008-9231-6.

Gales, M. E. J., \& Booth, R. L. (1975). A copper-cadmium column for manually determining nitrate. News of Environmental Research in Cincinnati. U.S. Environmental Protection Agency.

Gilbert, B. C., Hanson, P., Jones, J. R., Whitwood, A. C., \& Timms, A. W. (1992). EPR investigation into the kinetics and mechanism of the oneelectron reduction of benzenediazonium ions by $\mathrm{Fe}(\mathrm{II})-\mathrm{EDTA}$ and other iron(II) complexes. Journal of The Chemical Society-Perkin Transactions, 2(4), 629-636. doi:10.1039/p29920000629.

Grasshoff, K. (1964). Zur Bestimmung von Nitratin Meerund Trinkwasser. Kieler Meeresforschungen, 20(1), 5-11.

Grasshoff, K. (Ed.) (1999). Methods of seawater analysis. New York: Wiley.

Griess, P. (1879). Bemerkungen zu der Abandlung der H.N. Weselsky und Benedikt 'Uber einige Azoverbindungen'. Berichte der Deutsche Chemische Gesellschaft, 12, 426-428. doi:10.1002/cber.187901201117.

Henricksen, A., \& Selmer-Olsen, A. R. (1970). Automatic methods for determining nitrate and nitrite in water and soil extracts. Analyst (London), 95, 514-518. doi:10.1039/an9709500514.

Herzsprung, P., Duffek, A., Friese, K., de Rechter, M., Schultze, M., \& von Tümpling, W., Jr. (2005). Modification of a continuous flow method for analysis of trace amounts of nitrate in iron-rich sediment porewaters of mine pit lakes. Water Research, 39(9), 1887. doi:10.1016/j.watres.2005.02.017.

Ilosvay, L. (1889). Determination of nitrite in saliva and exhaled air. Bulletin de la Société Chimique de France, 3(2), 388-391.

Ito, A., Umita, T., Aizawa, J., Takachi, T., \& Morinaga, K. (2000). Removal of heavy metals from anaerobically digested sewage sludge by a new chemical method using ferric sulfate. Water Research, 34(3), 751758.

Kimball, B. A., Runkel, R. L., Walton-Day, K., \& Bencala, K. E. (2002). Assessment of metal loads in watersheds affected by acid mine drainage by using tracer injection and synoptic sampling: Cement Creek, Colorado, USA. Applied Geochemistry, 17(9), 1183. doi:10.1016/ S0883-2927(02)00017-3. 
Nydahl, F. (1974). Reduction of oxygen in aqueoussolution by electrolytically precipitated cadmium. Talanta, 21(12), 1259-1267. doi:10.1016/0039-9140 (74)80147-5.

Nydahl, F. (1976). Optimum conditions for reduction of nitrate to nitrite by cadmium. Talanta, 23(5), 349-357. doi:10.1016/0039-9140(76)80047-1.

Patton, C. J., Fischer, A. E., Campbell, W. H., \& Campbell, E. R. (2002). Corn leaf nitrate reductasea nontoxic alternative to cadmium for photometric nitrate determinations in water samples by airsegmented continuous-flow analysis. Environmental Science \& Technology, 36(4), 729-735. doi:10.1021/ es011132a.

QuickChem Method 10-107-04-1-A (1995). Nitrate/nitrite, nitrite in surface water, waste water, 0.2 to $20 \mathrm{mg} / \mathrm{L}$. QuickChem automated ion analyzer methods manual. Milwaukee: Lachat Instruments.

Shinn, M. B. (1941). Colorimetric method for determination of nitrite. Industrial \& Engineering Chemistry. Analytical Edition, 13(1), 33-35. doi:10.1021/ i560089a010.

Stainton, M. P. (1974). Simple efficient reduction column for use in automated determination of nitrate in water. Analytical Chemistry, 46(11), 1616-1616. doi:10.1021/ac60347a051.

Strickland, J. D. H., \& Parsons, T. R. (1965). A manual of seawater analysis. Ottawa: Fisheries Research Board of Canada.

Strickland, J. D. H., \& Parsons, T. R. (1972). Determination of reactive nitrate. A practical handbook of seawater analysis (pp. 71-80). Ottawa: Fisheries Board of Canada.

United States Environmental Protection Agency (1974). Method \# 353.3: Nitrogen, nitrate-nitrite (spectrophotometric, cadmium reduction). STORET No. 00630.

Vaughan, B., Howe, J., \& Peplinski, M. (1993). Minimizing interferences associated with cadmium reduction determination of soil nitrate. Communications in Soil Science and Plant Analysis, 24(9-10), 1003-1008. doi:10.1080/00103629309368856.

Vollhardt, K. P. C., \& Schore, N. E. (1994). Organic chemistry. New York: Freeman.

Wood, E. D., Armstrong, F. A. J., \& Richards, F. A. (1967). Determination of nitrate in sea water by cadmiumcopper reduction to nitrite. Journal of the Marine Biological Association of the United Kingdom, 47(1), 23. 